Кристијан А. ОЛАХ*

Институт за књижевност и уметност Београд
Оригинални научни рад

Примљен: 14.10 .2019 .

Прихваћен: 12.02.2020.

\title{
КОЈЕ ЈЕ ВЕРЕ ХАЗАРСКИ РЕЧНИК? Духовност форме Павићевог романа**
}

\begin{abstract}
У раду се указује на основне поетичке, тематске и значењске равни Хазарског речника Милорада Павића, који се заједнички могу свести под питање истине и њене субјективности. У светлу тог питања осветљена је и „површинска”, текстуална раван романа, изражена у енциклопедијској односно лексикографској форми. Та форма, сама по себи, сагледана као духовно биће, изражава, заправо, значењску усмереност романа: драму између првобитног „Хазарског речника”, у облику тела небеског Адама, чије је васпостављање спречено, и „садашњег” Хазарског речника, у виду књиге која истовремено и чува и замагљује сећање на то тело. Управо на темељу тих увида - у духовне аспекте значења (и) форме Хазарског речника - поставља се и питање симболичке ситуираности Павићевог дела унутар српске културе.

Кључне речи: Милорад Павић, Хазарски речник, метафизика, духовност, јерес, гностицизам, тело, књига.
\end{abstract}

Питање постављено у наслову овог рада - Које је вере Хазарски речник? - на први поглед изгледа необично, као да је спој неспојивог. Логично је, заправо, питање како неки текст може да има или да исповеда веру. Зато се чини да је довођење у везу вере и текста излишно: вера је, на крају крајева, неисказива и надтекстуална, док текст у себи може само да потхрани религиозну интерпретацију вере, да конзервира облик верске истине, да питање вере буде његов предмет.

Међутим, текст није само садржај већ и форма у коју је садржај оденут. А ако је форма, условно речено, тело текста, или тело смисла који провејава кроз текст, онда се може претпоставити да, где има тела - и душа је ту негде. Другим речима, у светлу оваквог метафизичког схватања односа садржаја и форме, књижевни текст ваља сагледати и као облик духовности, који чак

${ }^{*}$ kristijanolah84@hotmail.com

** Рад је настао у оквиру пројекта „Културолошке књижевне теорије и српска књижевна критика" (178013), који финансира Министарство просвете, науке и технолошког развоја Републике Србије. 
може да буде „самосвестан” у мери да одражава ону врсту искуства која се, још увек, грехом зове.

Наравно, овде се може отворити заграда и изнети аксиом да свако књижевно дело, па и Павићев роман о коме је реч, представља „духовно биће” не у некаквом објективном смислу, по себи, већ у смислу да на уметнички, а то значи битно редукован начин, одсликава духовност сопственог аутора. Духовно биће књижевног дела могуће је, притом, само као релационо биће, како у односу према аутору, тако и у односу према читаоцу. У лепези тог саодношења формира се и његов положај у култури. Прецизније речено, сам карактер духовног бића неког дела заслужан је, у извесној мери, кад је посреди положај тог дела унутар симболичких координата једне културе. Затворена заграда.

Да би се Хазарски речник сагледао као самосвесно, духовно биће у нареченом смислу, не би ли му се тако одредио духовни карактер, неопходно је интерпретативним напором спустити се у саму срж његове, не уметничке, већ духовне истине. Јер, проблем истине је кључни проблем овог романа, и да би се он разрешио, потребно је одговорити - као пред сваком сфингом - на три питања.

Прво питање од суштинске важности за тумачење романа гласи: у коју веру су прешли Хазари, или, другим речима, којој су се истини, јединој и коначној, наводно, запутили, односно, шта је истина хазарске полемике? То питање захтева да се најпре обрати пажња на смисао макроструктуре Павићевог романа.

У критици је Хазарски речник претежно тумачен као роман чије референцијално средиште представља са́мо хазарско питање, питање у коју веру су прешли Хазари, па се на основу тога дошло до закључка да је посреди дело које тематизује немогућност сазнања историјске истине. Сам поглед на макроструктуру романа то и потврђује. Три институционалне религије, представљене трима књигама из којих се роман састоји, држе до властитог историјског виђења разрешења хазарске полемике.

Међутим, роман овако склопљен - од три књиге од којих свака заступа своју истину - није прави „Хазарски речник”, већ његова фиктивна реконструкција, и то двострука, јер је и претходна, Даубманусова, била реконструкција некадашњег „Речника” хазарских ловаца на снове, или, боље рећи, идеје таквог „Речника”. Сходно Платоновој теорији уметности, као што је предмет представљен у уметничком делу удаљен од света идеја, тако је и „садашњи” облик Павићевог романа удаљен од сопствене истине - од њеног изгубљеног тела.

Индикативно је да је прва реконструкција „Речника”, уништена па поново реконструисана, настала 1691, у доба које је идеолошки било обележено просветитељством. Идеал верске или религијске толеранције, какав, рецимо, постоји у Лесинговом Натану Мудром (1779), у Даубманусовој реконструкцији „Хазарског речника” је формално отеловљен. То значи да сама форма романа изражава просветитељски идеал толеранције, идеал према коме не постоји једна једина Истина, са својим обавезујућим ко, нетолерантна према другим истинама, већ њихово равноправно, трпељиво, „демократско” више- 
гласје. Тај моменат препознат је и у критици која је, попут оне из пера Ханса Роберта Јауса, Павићев роман означила као један од најзначајнијих књижевних дела која собом исказују идеал хуманизма и толеранције.

Ако би се, имајући то на уму, ту макроструктуру романа, покушало, пре времена, са давањем одговора на питање из наслова, које је вере такав $X a$ зарски речник, односно његова фиктивна, двострука реконструкција, а чије текстуално биће изражава наречени идеал, онда би се могло претпоставити да је посреди „вера”, налик оној масонској, у некакво тзв. „врховно биће”.

Jep, ако је истина хазарске полемике изгубљена, као што јесте, онда ништа такву изгубљену историјску истину не представља боље од поређења са врховном инстанцом масонске квазирелигије која у себи садржи то ништа. „Врховно биће” је само ознака или празно поље које „еманциповани” и „толерантни” припадници монотеистичких религија испуњавају сходно сопственим веровањима. Није, дакле, посреди ни религијска синтеза или некакав синкретизам, већ компромисно одступање од ревновања сопственој верској или религијској истини. Толеранција се тако, парадоксално, испоставља као важнија од (исповедања) живота у Истини, од Истине која, бар према хришћанском веровању, јесте сам Живот.

Другим речима, форма Хазарског речника, ма колико представљала некакав позитиван, просветитељски идеал, истовремено, гледано са конзервативне, ревнитељске позиције, оличава јерес, или, прецизније, апостасију, отпадништво од Истине, једне и једине, од њеног тела - у случају, наравно, да таква истина постоји у самом бићу фиктивног света романа.

Каква истина или, боље рећи, какве онтолошке и метафизичке истине владају у фиктивном свету Павићевог најхерметичнијег дела? То би било друго по реду суштинско питање кад је посреди тумачење романа. Оно, заправо, указује на интерпретативни прелаз унутар саме истине: од њеног изгубљеног шта, до непознатог ко. Од исхода хазарске полемике - који тумача може одвести на погрешан траг - до питања које том исходу претходи: која је вера истинита? Јер, хазарска полемика је тако подешена као да њен исход одређује истинитост саме вере, а, заправо, одређује само реторичку убедљивост представника религије.

На крају, у коју веру су прешли Хазари није више ни важно, будући да су се они приклонили не Истини неке од трију вера, метафизичкој истини, оној која има онтолошко поткрепљење у фиктивном свету романа, већ „истини” неке од трију религија, а то значи текстуалној, институционалној, историјској, релативној истини, која је то само по имену.

Тумачење романа, на тај начин, не представља само - као и свако тумачење уосталом - потрагу или понирање, већ, сликовито речено, гностичку авантуру која за циљ има досезање метафизичке истине, скривене испод свих његових формалних и семантичких, но ипак текстуалних романескних фасада.

Као неке од тих фасада свакако ваља сагледати званичне религије - хришћанство, јудаизам и ислам. Без обзира на њихову међусобну трпељивост, изражену у макроструктури романа, а која метонимијски оличава и метафизичку поделу света између њих, оне су ипак фасаде јер њихове исти- 
не не кореспондирају са онтолошким уређењем фиктивног света романа. А са тим уређењем, односно са самим светом као таквим, кореспондирају, заправо, истине њихових ,,јереси”, оличене у учењима о Адаму, брату Христовом, Адаму Кадмону и Адаму Руханију. То значи да хришћанство, јудаизам и ислам нису истинити, већ су истините њихове ,јереси”. Или, тачније, посреди је травестија истине и јереси: јеретичке су те три званичне религије, а оно што се из њихове перспективе институционалне моћи представља као јерес, садржи истину коју оне немају нити су је икада имале. Без обзира на то, фиктивни свет романа је тако замишљен да званичне религије постоје са сврхом: оне морају да постоје, не би ли прикриле страшну тајну сопствених наводних , јереси”.

Jep, те наводне или такозване ,јереси”, исказане у обличју учења о три Адама, не представљају некакве откривењске истине, дакле оне нису истине у пуном смислу те речи, већ пре „шифре” које упућују на истину, прозраци кроз вео тајне. Реч је о учењима којима се у највећој мери, без обзира на надређене конфесионалне разлике, може приписати гностички карактер. Због тога је од њихове тајновите а по гностичком правилу просветљујуће истине, али која се овде само у смрти спознаје, важнији смисао учења који води до такве једне троцентричне али онтолошки упитне истине. Који је, стога, смисао тих ,јеретичких" учења? То би било треће питање од суштинске важности за тумачење романа.

Оно што је заједничко учењима о три Адама је мистички карактер његовог тела: тело првог, Адама, брата Христовог, састоји се од тзв. „епифанија” или, цвајговски речено, „звезданих” тренутака човечанске егзистенције; тело Адама Кадмона састоји се од слова, а тело Адама Руханија од снова. И једно и друго и треће тело Адамово је расуто, као што је, управо због тога, расута и лексикографска, енциклопедијска форма Хазарског речника. Ако та три Адама указују на пут који води ка Истини, онда сама форма Павићевог романа као да жели додатно и намерно да замагли тај пут, односно смисао тих учења у контексту хазарске полемике. Није, дакле, само макроструктура, изражена у виду три књиге, Црвене, Жуте и Зелене, субверзивна у односу на могућност разоткривања тајне романескног света, већ је и микроструктура, изражена у виду лексиконских одредница, такође у истом смислу субверзивна, будући да је наводни исправан начин њиховог комбиновања и читања, једини који читаоца може приближити тајни, означен као хибрис.

Међутим, ако је „садашња” лексикографска форма Хазарског речника реконструкција некадашњег Даубманусовог „Хазарског речника”, као што је и тај био реконструкција, каква је онда пра-форма тог некадашњег а изгубљеног „Речника”? Или, прецизније, како је прави „Хазарски речник” по својој суштини требало да изгледа? Шта је његово тело, тело које је тек сада представљено у коначном облику књиге, заправо требало да буде?

Одговор на то питање ваља потражити у учењу секте хазарских ловаца на снове. Као што су гностичке јереси у метафизичком смислу истинитије од званичних религија, тако је и учење хазарске секте, дакле не неке званичне хазарске религије, такође на истоветан метафизички начин истинито, па и 
на известан начин кореспондентно са гностичким јересима. У сржи учења и постојања хазарске секте ловаца на снове лежи подухват урањања у туђе снове и њиховог прикупљања и обједињавања у тзв. „хазарске речнике”. То значи да је прави „Хазарски речник” требало да од свих одсањаних снова твори једно мистичко тело. Гностичка учења би додала - тело Адамово. Тако се испоставља да и пре речи беше тело. Да се онемогућен подухват хазарских ловаца на снове не би поновио, било је важно да се истина тог подухвата заувек сакрије, да (п)остане тајна. Томе је требало да послужи фасада од речи, реконструкција некадашњег мистичког сновидовног тела у облику књиге са двоструко субверзивном и расутом формом.

Смисао ,јеретичких" учења - и то је одговор на оно треће постављено питање - јесте у субверзивној окренутости према онтолошком и метафизичком поретку фиктивног света романа. Сходно жељи лирски надахнуте принцезе Атех, заштитнице секте ловаца на снове, да се свет створи ,још једном, али на бољи начин” (Павић 2001: 36), одговара не само покушај ловаца на снове да саберу снове у тзв. „хазарске речнике” већ и гностичка учења о томе да се тело Адама може поново васпоставити само ако се саберу сви „епифанијски” тренуци, сва слова небеске азбуке поређана правилним редоследом, и сви снови. Поновним васпостављањем Адама наступа инверзна апокалипса и свет се ствара изнова, „али на бољи начин”. Шта онда лежи у пројекту ловаца на снове ако не поново васпостављено тело Адамово?

Два су, дакле, „Хазарска речника”: први је у замисли најсубверзивнијег људског деловања икад замишљеног, усмереног против самих темеља постојећег света, па и, следствено, људског рода таквог какав јесте, у име одстрањења зла, а други у субверзивној и истовремено безазленој форми књиге - јер такво је време наступило - која управо том својом субверзивношћу и безазленошћу настоји, парадоксално, да допринесе очувању постојећег поретка. Може се додати и да су та два речника, некадашњи у облику Адамовог тела, и садашњи у облику књиге, смртни непријатељи.

Лексикографска, енциклопедијска форма Павићевог романа оличава, дакле, напетост између вере у постојећи свет, свет који је у роману приказан кроз визуру антрополошког песимизма, и вере у нови свет чија је цена уништење овог постојећег. То значи да сама форма романа исказује драму космичких размера, и то драму за коју би се могло рећи да су јој и једни и други протагонисти демонског карактера. Да је подухват васпостављања Адама или тела тзв. „Хазарског речника” субверзиван и „демонски”, у то нема сумње. Обрт је у томе што поредак фиктивног света почива на упорном настојању демонских бића да га очувају. Фиктивни свет романа је троцентричан и у њему обитавају демони из сва три пакла о којима проповедају званичне религије. Управо ти демони, из хришћанског, јеврејског и исламског пакла, онемогућују да се у потпуности изврши подухват хазарских ловаца на снове, да се поново оформи тело Адамово, као и настојање да се сачува истина о том подухвату у форми Даубманусове реконструкције: дозвољена је само безазлена реконструкција претходне реконструкције у којој наречена истина, сходно идеалу толеранције, и захваљујући самој расутој форми, по- 
стаје још једна у плејади других истина. Да ли то значи да је и садашњи приређивач књиге, како сам себе назива, у ствари једна прикривена, демонска фигура? Јер, ако није, онда је њихов сарадник. У демонској је, па тек онда и људској, користи да свет почива на просветитељском идеалу толеранције, на равноправно подељеним истинама, на њиховој нивелацији: у супротном ће пропасти, а са њим и демонска бића. Са Натаном Мудрим или без њега: како год узели, избора, заправо, нема - зло тријумфује.

Некадашњи „Хазарски речник”, који никад није био довршен, представљало је мистичко тело Адамово, док је садашњи његова реч, но извитоперена, реконструисана, која једино још својим формалним уређењем чува сећање на то тело. Јер, иако расуто, Адамово тело је оно које је стварно, а форма романа је метафора тог тела. Таква реч, дакле, више не може да постане тело. Тајна транссупстанцијације не функционише у реконструисаном, неаутентичном, расутом погледу на свет; она је овде најзад изгубљена. Затеченом, у таквом свету, пред тајном постојања, читаоцу остају само задовољства у тексту, тексту састављеном од снова, и, можда, још понеке радости „вредније од самог читања” (Павић 2001: 387). Али, кад нема више сећања на предвечног Адама, да ли је све то сада постало бесмислено? Односно, ако се питање другачије постави, зашто би било?

Право питање у том смислу гласи: да ли и читалац постаје део семантичке мреже романа, па његово дописивање нових одредница, као одраз апела приређивача, односно покушај читања у правилном редоследу већ постојећих одредница, представља такође демонску работу? Ако читалац самим чином читања постаје сутелесник Адамовог тела, макар то тело било посредовано кроз двоструку текстуалну реконструкцију, ако дакле, тим чином из мртвила постојања прелази у истински живот, да ли је већ самим отварањем корица Павићевог романа начинио грех? То зависи од начина на који се жеља принцезе Атех сада, у овом свету, може протумачити. Једно од решења је да се свет више не може изнова створити, нити зло одагнати, али да се сам свет може побољшати: о томе сведочи Хазарски речник. Павићев роман, као сведочанство једног грандиозног метафизичког неуспеха, упућује на то да се и из таквог једног неуспеха могу изродити прворазредне културне вредности. Управо се културним стваралаштвом, и стваралачким читањем какво роман захтева, а којим се сама стварност дубље и истинитије сагледава, свет чини бољим местом. Радости „вредније од самог читања” може подарити само стваралачки испуњено време, време испуњено културом и књижевношћу. Чак и кад прети ништавило, ваља стварати, јер се ширење ништавила тиме успорава: попут Леандровог зидања цркава пред турском најездом у Унутрашњој страни ветра. Попут поруке оне путнице из Хазарског речника која схвата да није важан циљ, колико сам пут, ма колико, из перспективе циља, тај пут био узалудан (Павић 2001: 182). Додуше, Павић се Хазарима вратио у роману Друго тело, тврдећи чак, на једном месту, да реч обнавља живот, и да „може добити ново тело” (Павић 2006: 228). Да ли то значи да су речи заузеле некадашње место снова, и да се књижевношћу свет може изнова 
створити, у смислу да буде бољи и лепши него пре? Несумњиво је да се у тим речима крије смисао стваралаштва по Милораду Павићу.

Као одговор на питање постављено у наслову овог рада, може се закључити да, будући да Хазарски речник Милорада Павића садржи у себи два „Речника”, онај старији у облику тела и овај новији у форми књиге, но која je, та форма, сама по себи метафора некадашњег тела, и одговор на питање које је вере роман мора да подразумева ту двострукост. Било да „верује” у нови или постојећи фиктивни свет, та вера је демонског порекла, уз ограду да се, кад је реч о стварном свету, ублажава читалачком, односно културном, стваралачком апологијом. Зато је Павићев роман, у двоструком смислу, гностичког и јеретичког, односно субверзивног и рушилачког карактера, али који ипак апелује на стваралачке човекове потенцијале.

Напослетку, ваља се изнова питати да ли је необична судбина тог романа у окриљу културе у којој је настао, последица преливања тог његовог јеретичког и субверзивног карактера. Јер, да ли је Милорад Павић данас, слављен у свету излазећег сунца, као што је некада био слављен на Западу, и даље пре свега српски писац? Да ли се његово дело и даље осећа удобно у српској култури? Имајући у виду сеобу његове славе, или, боље рећи, читалачке потребе за његовим делом, али потребе која се временом географски премешта, може ce, накратко, застати и пред чињеницом, која можда указује на некакву вишу промисао, да је Милорад Павић на онај свет отишао истог дана и истог месеца кад и писац Сеоба. Јер, није редак случај да по извесним својим дометима неко дело превазиђе оквире тзв. матичне културе и њеног духовног миљеа, и да буде боље прихваћено у неким другим културама. Чини се као да је овде посреди такав случај: као да се сам Хазарски речник изместио из књижевности и културе без које га, иначе, не би ни било. У коју је веру прешао? Да ли је то питање логични и горки завршетак хазарске полемике која је у њему тематизована, или је, пак, реч о изазову који још увек није добио достојан одговор? Можда, на крају, не треба превише бринути ако тај одговор изостане: докле год духовна и културна авитаминоза буде владала, па чак и ако се на Истоку буде угасила, доћи ће нека друга времена и Павићево дело, са Хазарским речником на челу, остаће и даље на позорници људског интересовања. А заправо, да ли само људског?

\section{ИЗВОРИ}

Павић 1992: М. Павић, Унутрашња страна ветра, Београд: Просвета. Павић 2001: M. Pavić, Hazarski rečnik [ženski primerak], Beograd: Dereta. Павић 2006: M. Pavić, Drugo telo, Beograd: Dereta. 


\title{
ЛИТЕРАТУРА
}

Jayc 1997: Х. Р. Јаус, „Павићев Хазарски речник”, превела са немачког Љубинка Петрин, Кюижсевност, год. 51, књ. 102, св. 1/2, стр. 245-252.

Jayc 2014: Х. Р. Јаус, „Разговор религија или The last things before the last”, превео с немачког Дамир Смиљанић, Летопис Матице српске, год. 190, књ. 494, св. 1/2, стр. 61-94.

Лесинг 1998: Г. Е. Лесинг, „Натан Мудри”, превела са немачког Александра Бајазетов-Вучин, Мостови, год. 29, св. 2, бр. 115, стр. 267-376.

Олах 2012: К. Олах, Кюига-Бог: (Постмодерна) духовност у Хазарском речнику Милорада Павића, Београд: Институт за књижевност и уметност.

\author{
Kristijan A. Olah \\ WHAT IS THE FAITH OF DICTIONARY OF THE KHAZARS? \\ The spirituality of the form of Pavić's novel
}

\section{(Summary)}

This paper addresses elementary poetic, thematic and semantic horizons of Milorad Pavićs Dictionary of the Khazars, jointly regarded as the question of truth and its subjectivity. In light of this question, the "superficial" textual horizon of the novel is presented, expressed in an encyclopedic or lexicographical form. This form, itself, regarded as a spiritual being, actually expresses the semantic direction of the novel: drama between the original "Dictionary of the Khazars", in the form of the body of the heavenly Adam, whose incarnation was prevented, and "present" Dictionary of the Khazars, in the shape of a book that is both preserving and blurring memories of that body. Exactly based on these insights - into spiritual aspects of the form (and the) meaning of Dictionary of the Khazars - the question of symbolical position of Pavić's work within the Serbian literature is being presented. 